\title{
Levonordefrin Hydrochloride
}

National Cancer Institute

\section{Source}

National Cancer Institute. Levonordefrin Hydrochloride. NCI Thesaurus. Code C99566.

The hydrochloride salt of levonordefrin, a synthetic catecholamine and norepinephrine derivative with sympathomimetic and antihypertensive effects. Levonordefrin's antihypertensive effect is exerted through activation of alpha 2-adrenergic receptors in the cardiovascular control center of the CNS thereby suppressing the sympathetic output from the brain and subsequently lowering blood pressure. Levonordefrin binds to and activates peripheral alpha 2- adrenergic receptors, thereby causing vasoconstriction. 